\title{
Flattening COVID-19 Curve in Rivers State Nigeria; Issues in Second Lockdown and Physical Distancing of Diobu Axis of Port Harcourt
}

\author{
Maduawuchi Elem* \\ Sociology Department Ignatius Ajuru University of Education Rumuolumeni, Port Harcourt, Nigeria \\ *Corresponding Author \\ Maduawuchi Elem
}

\section{Article History}

Received: 12.02 .2021

Accepted: 23.02 .2021

Published: 28.02.2021

\begin{abstract}
The work is a qualitative paper that focused attention on evaluating Rivers State government COVID-19 second lockdown and physical distancing of Diobu area of Port Harcourt. The study was informed by why the flat disregard by the residents of the area for such life-saving health policy to the extent that government isolated the area for another phase of lockdown when it relaxed lockdown in other areas of the state. At the end, the core reason for the people general disobedient is that lockdown contradict the peoples' age long informal economy business practice which provide them with daily money without savings among other reasons. This finding of this work has significant relevance in other related empirical literatures on lockdown and physical distancing in low income and informal dominated population. Based on this, the work recommend, in case of similar case, more concentration of palliative and cash gift to such highly low income population with daily income as this will remove the worries associated with lockdown which is strange to them.
\end{abstract}

Keywords: COVID-19, lockdown and physical distancing.

\section{INTRODUCTION}

History is rich in the existence of disease outbreak that has interrogated humanity. In 1918, Spanish flu infected not less than $27 \%$ of the world's population for three years. In this, mortality estimates range from 17 to 50 million globally [1]. In 1957, Asian flu occurred with mortality estimate at 1.1 million [2]. In 1968, A/H ${ }_{3} \mathrm{~N}_{2}$ influenza shocked the world, claiming about 1 million deaths. In 2002, SARS emerged in China and claimed so many lives. Campedelli, Aziani and Favarin claim that between November 2002 and July 2003, the disease claimed 774 lives with 8,098 infections in 2009, Swine flu breakout in United State and spread to many nations with not less than 61 million cases in United States alone. The least is endless with diseases like laser fever, Ebola, Human Immune Deficiency Syndrome, Bird flu etc. The phenomenon is very likely to play out in the future.

Like other pandemics, Coronavirus disease, also called COVID-19 is quite unique. The manner in which it punctured and undermined developed world's health infrastructure, the speed with which it collapsed developed nations' social and physical boundaries to claim lives and its sudden deep impacts on developed economies is outstanding. It is based on this disease's ability to spread to other nations that World Health organization (WHO) considered it as Public Health Emergency of international concern on $31^{\text {st }}$ January 2020 and consequently classify it as a pandemic on $11^{\text {th }}$ March 2020 [3].

Furthermore, the manner with which the virus crumbled developed world's health infrastructure, Ayadi [4] claim that Covid-19 has shown to the world that no government from either developed and developing nations are equipped and are ready to prevent or manage such an abrupt external shock. This unhindered spread is in the face of containment measures like travel bam, restriction, mandatory quarantine, lockdown and social distancing, progressive testing, awareness campaigns. In this, underdeveloped nations with gross under funded health system were engulfed with uncertainty. However, virtually all nations made bold efforts to confront the problem especially social distancing and lockdown which seem somewhat enforceable containment strategy. On this basis, Rivers State government, noting how

Copyright (C) 2021 The Author(s): This is an open-access article distributed under the terms of the Creative Commons Attribution 4.0 International License (CC BY-NC 4.0) which permits unrestricted use, distribution, and reproduction in any medium for noncommercial use provided the original author and source are credited. 
the developed world recorded high fatality and is still recording more, imposed lockdown and social or physical distancing to reduce the spread of Covid-19 to protect live of the people and reduce its negative impacts on their venerable economy

\section{The Problem}

Since the outbreak of Covid-19 in main land China, the disease has claimed more deaths than any known outbreak in the world. Within two weeks of its outbreak on 2/1/2020 February 2020 the growth rate is exponentially phenomenal [3]. Hubei Province, the epicenter of the virus outbreak had a monumental growth rate as the confirmed cases rose from 270 to 11,000 within the same period. In other Chinese cities, confirmed cumulative cases within the same period rose from 60-6000. By March, the total confirmed cases rose to 67,800 in Hubei with 50 new cases per day in other Chinese cites. Given its spread, China rolled out an ambitious, agile and aggressive disease confinement efforts in history (The WHO- China Joint Mission report, 2020) in Zhang, Wang, Chang, Wang Xu, Yu, Tsamlag, Long, Wang and Cai [6]. In these, china spend not less than 9.95 billion CNY (approximately, 144 billion USD) in funds for public health service and epidemic prevention. In the midst of such robust programme, by April $18^{\text {th }}, 2020$, the mortality rate due to the virus rose to $0.3 / 100000$ in China [5].

By Mach $7^{\text {th }} 2020,94$ countries have had 11, 927 confirmed cases of Covid-19. In this, the development world has suffered immensely. In Belgium, a country with 11 million people have had reported deaths from Covid-19 than China. Aiger [7] report that Belgium had 57 fatalities per 100,000 inhabitants. This is the highest death rate in the world. Since its emergence in France, the country recorded 76, 246 deaths from 1/3/2020 to 6/4/2020. When the virus got to Italy, in a certain day, death toll rose from 427 to 475 [8]. At a certain time, Italy fatality rate was higher than China. In United States, it become a calamity as it over run United States' sophisticated health care system. It is a leading cause of death in United States. The daily United States mortality rate for Covid-19 deaths is equivalent to the September 11, 2020 attacks which claimed 2988 lives, occurring every 1.5 days or 15 airbus 320 jetliners, each carrying 150 passengers, crashing every day [9]. These incidences among so many others made WHO to declare Covid-19 a pandemic disease and public health problem [10]. In all these, its impacts on developed economies were devastating. According to Pak, Adeqboge, Adekunle, Rahman, Mcbryde and Eisen [10] since the start of the year, leading US and European stock market indices have lost a quarter of their value, with oil prices declining by more than $65 \%$ oil price as of April 24 , 2020. These result to unemployment level in most developed nation.

Given the spread rate and the raising death rate, government all over the world, including Rivers State government introduced containment measures to break the spread the of the virus to save people's life. Among such policies is lockdown and social distance or physical distancing. In Rivers State certain areas witnessed second lockdown or isolated cases such containment policy even when government has relaxed lockdown policy. This became imperative due the general disregard for the policy by the residents of the area or there is a recorded case of Covid-19 incidence in the area. The issue is why this flat disobedient by the residence? Does this disobedient have anything to do with the people's daily income business nature which does not create room for them to make savings for emergency like lockdown? These questions form the imperative for this work.

\section{STUdy Area}

Diobu is one of the heavily populated low income communities in Port Harcourt, the capital of Rivers State, Nigeria. The area expands from mile one, mile two and mile three area. Diobu shares boundary with new Government Reserve Area (GRA) in the north, D-Line in northwest, kidney island in the southeast; Rivers State University in the northwest and Eagle Island in southwest. The area hosts the largest open markets-mile one and mile two including timber markets and stores. Most of the residence lives below the poverty level. As very low income residential area, the area is notorious for gang activities, vices, kidnapping, cultism, and arm robbery. In fact, the areas are one of the most unsafe places to live in Port Harcourt. These vices are sustained because of the slum nature. From 1991 census, this part of Port Harcourt accounted for about $60 \%$ Port Harcourt population of 440,999 [11]. According to these scholars, at least $80 \%$ of the housing stock in Diobu date back to 1950s and 60s, therefore in most parts of the city, there is manifest obsolescence of the housing stock, overcrowded, poor access roads, poor waste management, inadequate social services and plethora of other pathological conditions that fit a slum area. This area is often the choice of low income people who came to stay in Port Harcourt. Given Port Harcourt terrain, the area accommodates so many waterfronts slums. With this, neighbors share very close informal relationship, thus social distancing is totally out of place.

\section{LiTERATURE REVIEW}

Covid-19 is a novel coronavirus caused by Severe Acute Respiratory Syndrome (SARS) [4]. It started in 2019 in Wuhan, China on $31^{\text {st }}$ December, 2019 with pneumonia- like symptoms [12]. As SARS, the virus transmission is high. Its symptoms aside respiratory problem, can lead to multi-organ failure and death. It can survive up to 72 hours on hard, 
shiny surfaces. This quality makes, the virus highly contagious when robust preventive sanitary measures are not taken. Given its virulence and its rate of transmission, China government opt for lockdown and physical distancing as a measure to break the rate of transmission. Lockdown and physical distancing also called social distancing are deliberate effort to slow down Covid-19 spread.

Shortly after its emergence in China, the virus gained speedy entry into over 210 countries and territories as it April 2020 through droplet transmission. As of April 2020, the disease fatality reached 200,000 with total infection estimated at 3 million globally. The rate of its spread makes the option of lockdown and physical distancing which entails closing partially or wholly social activities such as business, travel ban or any human gathering that will facilitate social contact and promote the spread of the virus imperative. It is believed that these options will not only reduce transmission but will also quicken the death of the disease since it cannot survive outside human being within some hours.

From the above exponentials spread of Covid-19 and its consequences, Diobu exist of Port Harcourt suffered an isolated lockdown when they flatly disobeyed government COVID-19 containment policy. The intent of government here is not punitive, rather to save life which of course is the core responsibility of government. This is more given the population density of the area. Sahasranaman and Jensen [13] in a study of spread of Covid-19 in urban neighborhoods and slums of developing world, using stochastic network model in the study, took two kinds of neighborhoods: slum and non-slum in their study. At the end, it was revealed that distribution of cases of epidemic were unequal even in peak and cumulative cases against places with informal settlement. In a related study by Onditi, Obimbo and Nyadera [14] on modeling a pandemic (Covid-19) management strategy for urban slums using social geometry framework conducted in densely populated informal settlements (slum) in Kenya, review that social distance approach did not work because its containment policy did not recognize the social-cultured and economic livelihood of such informal settlements. As a result of this, most residence failed to obey lockdown and social distancing rule.

In another study by Manisha [15] titled Covid-19 exposes fault line in peri-urban area in India reveal that government lockdown policy was well intended, but cannot work in a residence that is dependent on daily income who also do not possess cash liquidity to sustain such period. Amaechi, Sodipo; Nnaji, Owoyemi, Omittem, Okedo- Alex; Eborime and Ajumobi [16] in a similar study in sub-Saharan Africa reveal that social distancing is a vital containment measure for covid-19, but must take into consideration social-economic and broader peculiarity of the sub-Saharan Africa, otherwise, it will produce adverse result.

Awofeso and Irabor [17] in assessment of government response to socio- economic impact of covid-19 pandemic in Nigeria observed a bearing between covid-19 pandemic and low socio-economic livelihood in Nigeria [20]. This reason informed why the order was disobeyed. Beside this, the study also observed that it is difficult to observe social and physical distancing even good hygiene practice in a high density and poor houses. Citing Adesiyi [4], these scholars reveal that most residential houses in Nigeria are without good toilets, drainage system and inadequate waste facilities and space. Stressing further, this work discovered that since most Nigeria workers are employees of informal sector who hitherto depend daily on face-to-face interactions for their business, lockdown cannot achieve the very intent. Given this age long practice, it will be difficult for the people to obey lockdown policy because it will greatly affect the people income level, savings, expenditure and life style generally.

Wasdam and Prasad [18] in a typical study of government containment or the possibility of the use of social distancing among urban poor reaffirm that in such related environment, the prime minister of India introduced what these scholars called draconian measures like travel bans, stringent screening protocols at the airports, social distancing and restriction of movement among others. These scholars observed that for slum residence, social distancing is more an aspiration than any attainable reality. That is, social distancing is better in theory than in practice in slum or densely populated area. This is because residence has long enjoyed intimate proximity to one another with porous walls and small communal spaces. Given this, the level of compliance was low because of the nature of slum area, the residence (as daily wage earner) and failure of government social welfare scheme to meet the people's need during the lockdown.

Other studies by Dorizzo and Gurither [19] on poor slum neighborhood in Accra and Johannesburg reveal that most respondents sees social distancing and lockdown as too extreme options. Base on their understanding, most of them did not obey the policy. These scholars conclude that lockdown and social distancing containment is only effective and will be useful with a well-informed population who perceive their government action as appropriate and who have access to social infrastructural standard specified by WHO [21].

\section{CONCLUSION AND RECOMMENDATION}

What is very clear is that lockdown and physical distancing containment is good to reduce the rate of covid-19 spread ordinarily. In the context of his work, it is a misapplication, thus cannot produce the expected intention of keeping people at home. This brand of containment can be effective where the population is not heavy, not low income, not 
dominated by people with daily income and where the housing pattern do not promote intense informal relationship that has been over time. Where the place is dominated with informal economy and with near absence of government presence, obedience to such policy is simply a false imagination. In this circumstance, lockdown and physical distance cannot achieve the covid-19 government objective. By their face-to-face interaction, covid-19 will spread. With lockdown hunger will kill them. But do they believe in the existence of the virus?

Diobu is populated by low income and are equally either very illiterate or close to it. In the heat of the covid-19, most low income and illiterates sees the virus as non-existence. In fact, in Nigeria, among the ordinary people COVID-19 is a conspiracy of the ruling class to divert public fund to their personal pockets. Besides this, most low income majority sees the diseases as the virus of the rich or the elites. This thinking appeal to most people in this category as most deaths and those who are infected are the rich. Also important is Nigerians general distrust or lack of trust by most Nigerians on their government, thus most low income people see it as a sham. In worst scenario, CVID-19 is malaria.

In slum environment or near slum environment like Diobu, where there is no social infrastructure like public water, it is not possible to accept social distancing or even the hygiene option of washing of hands. Where will you get the water to constantly wash your hands? It is simply a mirage. These made Diobu residents to disobey lockdown and social distancing policy of government in covid-19 which inform the reason for the second lockdown and strict imposition of social distancing of Diobu axis of Port Harcourt by Rivers State Government.

However this option can achieve its government objectives if government had concentrated the palliative distribution more on the areas like Diobu with heavily population of low income residence. Similarly, government can as well, provide cash gift since this class depend on daily paid job. This will serve as a very close substitute for the daily paid income they get. A combination of effective food palliative distribution for such people and cash gift will resource the worry which lockdown barred them from and which affected their daily food need which lead to their disobedient and government placemen of second lockdown on the area. With these the people can afford to stock their home and stay at home too. In the interim, government should embark on extensive provision of water and monitor social distancing when the facility is accessed.

\section{REFERENCES}

1. Taubenberger, J.K., \& Morens, D.M. (2016). 1918 Influenza: The mother of all pandemics, 12(1).

2. Campedelli, G.M., Aziani, A., \& Favarin, S. (2020). Exploring the effects of Covid-19 containment policies on crime: An empirical analysis of the short-term aftermath in Los Angeles forthcoming at American Journal of criminal justice.

3. Maier, B.F., \& Brockmann, D. (2020). Effective containment explains sub- exponential growth in recent confirmed Covid-19 cases in China American Association for the Advancement of Science 368, (6492): 742-746.

4. El Ayadi, A., Jay, J. W., \& Prasai, A. (2020). Current approaches targeting the wound healing phases to attenuate fibrosis and scarring. International journal of molecular sciences, 21(3), 1105.

5. Mi, Y., \& Cao, Y. (2020). Estimating the instant case fatality rate of Covid-19 in China. International journal of infectious Diseases, 97.

6. Wang, H., Wang, Z., Dong, Y., Chang, R., Xu, C., Yu, X., \& Cai, Y. (2020). Phase-adjusted estimation of the number of coronavirus disease 2019 cases in Wuhan, China. Cell discovery, 6(1), 1-8.

7. Ainger, J. (2020). Why the world's highest virus death rate is in Europe's capital. Bloomberg. Com.

8. Bishop, K. (2020). Italy's death toll from the coronavirus overtakes China's CNBC. Cau

9. Woolf, S.H, Chapman, D.A., \& Lee, J. H. (2020). Covid-19 as the leading death in the United States. American Medical Association, 325(2).

10. Pak, A., Adegboye, O. A., Adekunle, A. I., Rahman, K. M., McBryde, E. S., \& Eisen, D. P. (2020). Economic consequences of the COVID-19 outbreak: the need for epidemic preparedness. Frontiers in public health, 8.

11. Obinna, V.C., Owei, O.B, Ede, P., \& Ojumoro, A. (2009). Housing stress and urban renewal imperatives in Diobu, Port Harcourt, Nigeria. Journal of Geography and Regional Planning 2(7).

12. Musinguzi, G., \& Asamoah, B. (2020). The science of social distancing and total lockdown: Does it work? Electronic Journal of general medicine, 16(6).

13. Sahasranaman, A., \& Jensen, H.J. (2020). Spread of covid-19 in urban neighborhoods and slums of the developing world. Journal of the Royal Society Interface.

14. Onditi, H., Obimbo, M., \& Nyadera, I. (2020). Modeling a pandemic (covid-19) management strategy for urban slums using social geometry framework. The European journal of Development, 32:1450-1475.

15. Manisha, M. (2020). Covid-19 exposes fault lines in peri-urban areas. Down-to-earth.org

16. Amaechi, U. A., Sodipo, B. O., Nnaji, C. A., Owoyemi, A., Omitiran, K., Okedo-Alex, I. N., \& Ajumobi, O. (2020). Social approaches to COVID-19 pandemic response: effectiveness and practicality in sub-Saharan Africa. The Pan African Medical Journal, 37(Suppl 1). 
17. Awofeso, O., \& Irabor, P. A. (2020). Assessment of Government Response to Socioeconomic Impact of Covid-19 Pandemic in Nigeria. Journal of Social and Political Sciences, 3(3).

18. Wasdani, K.P. \& Prasad, A. (2020). The impossibility of social distancing among the urban poor: The case of an Indian slum in the times of Covid-19. International Journal of justice and sustainability 25(5).

19. Durizzo, K., \& Gunther, I. (2021). Managing the Covid-19 pandemic in poor urban neighborhoods: The case of Accra \& Johannesburg. World development, 137.

20. Economic consequences of the Covid-19 outbreak: the need for epidemic preparedness. Front Public Health 8:241.

21. Keni, R., Alexander, A., Nayak, P.G., Mudgal, J., \& Nandakumar, K. (2020). Covid-19: Emergence, spread, possible treatments and global burden. Frontiers in public health frintiersin.org.

CITATION: Maduawuchi Elem (2021). Flattening COVID-19 Curve in Rivers State Nigeria; Issues in Second Lockdown and Physical Distancing of Diobu Axis of Port Harcourt. South Asian Res J Human Soc Sci, 3(1): 32-36. 